\title{
Review of Dennis C. Rasmussen's The problems and promise of commercial society: Adam Smith's response to Rousseau. U. Park (PA): Pennsylvania State University Press, 2008, 208 pp.
}

\section{CHAD FLANDERS}

Saint Louis University

As its title suggests, Rasmussen's short but elegant book is about the relationship between Adam Smith and Rousseau, a relationship about which, Rasmussen notes, only a "handful" of articles and book chapters have been written (p. 6n. 8). Rasmussen's book will surely go a long way towards filling this scholarly gap, although it certainly will not (and probably should not) be the last word on the subject.

Rasmussen organizes his book by way of objections Rousseau makes to commercial society and Smith's responses to them. What emerges from Smith's replies to Rousseau, Rasmussen says, is a "deeper, more thoughtful Smith" (p. 6), one who both "unreservedly advocate[s] commercial society", but who also "accepts-indeed, insists-that many problems are associated with it" (p. 7). Rousseau saw commercial society as unhappy, and so too did Smith, for many of the same reasons. But Smith, on Rasmussen's telling, also sought to rebut or at least diminish the force of Rousseau's objections.

What does Rousseau find wrong with commercial society? Briefly, commercial society produces great inequalities of wealth, makes people weak and indolent, leads them to rely on the opinions of others for their sense of themselves and for their well-being, and creates desires in people that it (commercial society) cannot satisfy. The bottom line-for Rousseau-is that with commercial society we may have procured prosperity, but "at the cost of our goodness and our happiness" (p. 40). "Commercial society, in short, produces people who are good neither for themselves nor for others" (p. 40).

Although it would later be carried on, magnified, and given additional nuance by others (Marx, Nietzsche, Thoreau, and even Smith), Rasmussen maintains that Rousseau's critique was the most comprehensive and still "represents the greatest challenge for someone who hopes to defend commercial society" (p. 49). Rasmussen believes 
that Smith was able to make this defense of commercial society, and make it successfully. The majority of Rasmussen's book is taken up in showing how.

The key move of Smith's defense-according to Rasmussen-is to demonstrate that the advantages (prosperity, liberty, and security) of commercial society outweigh its flaws, which anyway are not "as numerous or as great" as the flaws of other, earlier forms of society (p. 6). As Rasmussen summarizes in his final chapter, "Rather than simply claiming that commercial society is good or bad, Smith constantly asks, 'In comparison to what?'” (p. 158). Commercial society, Rasmussen concludes, was for Smith (as it should be for us) "the worst form of society except for all the others that have been tried" (p. 175).

Before turning to Smith's response we might want to pause and consider what the goal of Rousseau's critique of commercial society was, precisely. It is probably wrong to think of Rousseau's portrait of primitive man in his second Discourse as urging us to return to an earlier state of nature. Surely in this regard we must take seriously Rousseau's starting point in that piece, viz., that he is going to begin by "setting all the facts aside" and that his researches should not be taken for "historical truths". We were never in paradise.

So Rousseau is not necessarily arguing that we can or should forsake commercial society because we were better off (happier, more equal) earlier. What Rousseau may be arguing, instead, is that we should refuse to be content in commercial society; that the proper attitude toward commercial society should not be one of endorsement, but one of detachment and alienation. Rousseau at many places in his work could simply be saying that we may never be happy, given our plight (pp. 4748).

If this is so, then we might wonder whether Rasmussen's (and according to Rasmussen, Smith's) strategy of showing that commercial society is better off than pre-commercial societies were in terms of wealth and the distribution of wealth might not directly be to the point. Merely challenging Rousseau's empirical claim that commercial society results in inequality of wealth does not seem the best way to rebut Rousseau on the damaging effects of commerce (especially if the problem is luxury itself: an equal distribution of luxury does not solve that problem). Nor will it do to say that the riches of commercial society will enable it to pay for education for the poor, thus making up for the stultifying effects of the division of labor on them (p. 110). This latter 
claim is akin to allowing a company to pollute on the ground that the taxes it pays will go towards environmental clean-up. This may persuade the pragmatic environmentalist, but not the one who is pure of heart. (The pure of heart will not be persuaded to sell his soul because the benefits outweigh the costs.)

A better sort of response to Rousseau might be to show that, despite the evident disadvantages of commercial society, we can still reconcile ourselves to living in such a society, and that there is nothing morally wrong about being so reconciled. Rasmussen and Smith approach this kind of response when dealing with Rousseau's critique that in a market society we only worry about seeming to care about other people, or seeming to be virtuous, not about actually being caring, or being virtuous. Smith's reply is that seeking the approval of others can give us a powerful incentive to actually be moral. Moreover, in order to get ahead in commercial society, one must really care for the interests of others and not just seem to; one must also exercise the real virtue of prudence (p. 122). Finally, although citizens must still depend on the opinions and actions of others in commercial society, citizens are not dependent on any one person, which gives them "an independence that the serf, the spaniel, and the ambitious poor man's son lack" (p. 124).

This response to Rousseau strikes me as more promising than simply totaling up the benefits of commercial society and discovering that they outweigh the costs (see, pp. 91, 129). Rasmussen has Smith saying that morality may depend on the opinions of others, and that commercial society may actually foster a certain type of virtue, not destroy it. Here the argument is not, or not entirely, that while commercial society corrupts us, it nevertheless has other, countervailing advantages. Rather, the argument is that commercial society in fact can better people, and better them morally.

In chapter 4, by far the most interesting and novel chapter in the book, Rasmussen sets out to solve an apparent paradox in Smith. Smith defends a kind of society that encourages people in the mad pursuit of material goods, while simultaneously insisting that material goods cannot and will not make us happy (here Smith obviously echoes Rousseau). Rasmussen puts the paradox carefully and pointedly, calling it "one of the most fundamental and puzzling questions of Smith's thought". Why does Smith "advocate commercial society if it undermines people's happiness?” (p. 131). 
Rasmussen's attempt at a solution to this puzzle is unsatisfying, although one cannot fault him for trying. For Smith, Rasmussen writes, commercial society is defensible because it provides liberty and security for "more than a relatively small number of individuals" (p. 144), and liberty and security are the prerequisites for happiness. Putting it another way, while commercial society may not guarantee happiness, it nonetheless removes two chief obstacles to happiness: dependence and insecurity (p. 131).

But the problem with this answer is that elides the fact that commercial society, on its way to removing dependence and insecurity, itself produces its own barriers to happiness. In order for commercial society to survive and prosper, people must pursue the baubles and trinkets that cannot in the end satisfy them. "People typically think they would be happier if they had more money", Rasmussen writes in an earlier chapter, "but Smith argues that this false belief actually tends to lead to unhappiness" (p. 86). Although liberty and security may be goods in their own right and moreover goods which commercial society supplies, commercial society also fosters conditions which make us unhappy in spite of being free and secure. We are back to being faced with the paradox: commercial society undermines people's happiness, yet Smith advocates it.

Rasmussen's work is useful because it forcefully shows us the manifest tensions in Smith's thought (chapter 4 may be the best example of this). It is perhaps this paradoxical quality that makes Smith's work so engaging, and why he deserves to be wrestled with as a moral philosopher. Rasmussen may not have resolved the tensions in Smith's work that he illuminates so well, but he puts those tensions into sharp relief, a necessary step in resolving them-if such a resolution is to be had.

Chad Flanders is assistant professor of law at Saint Louis University. His research interests include election law, criminal law, religion, and the philosophy of Adam Smith.

Contact e-mail: <cflande2@slu.edu> 